\title{
HISTÓRIA DAS FORMAS E OS TONS DA CRÍTICA: UMA RELEITURA DE O GRAU ZERO DA ESCRITA, DE ROLAND BARTHES
}

\author{
History OF FORMS AND THE TONES OF CRITICISM: \\ on Roland Barthes' Writing Degree Zero \\ Márcio Renato Pinheiro da Silva
}

Universidade Federal do Rio Grande do Norte / FAPESP

Currais Novos, RN, Brasil

Palavras-chave: História da literatura; modernidade; retórica; Roland Barthes.

Keywords: Literary history; modernity; rhetoric; Roland Barthes.

Mots-clés: Histoire littéraire ; modernité ; rhétorique; Roland Barthes.

\section{Resumo}

Em princípio, pode-se dizer que O grau zero da escrita (1953), primeiro livro do ensaísta francês Roland Barthes (1915-1980), consiste em uma história da literatura moderna de meados do século XIX a meados do XX. Ocorre que, nesse processo, Barthes se vale de pouquíssimos dados relativos tanto à história geral quanto à história da literatura, tornando o livro, ainda hoje, de delicada compreensão. Este artigo pretende se dedicar aos possíveis sentidos dessas lacunas, vinculando-as à particularidade mesma da história visada por Barthes (uma história das formas literárias modernas). Em seguida, será realizada sua contraposição ao tom assumido pela escrita do ensaísta diante da história por ele mesmo narrada, na tentativa de identificar e de discutir suas possíveis ambivalências.

Abstract

Initially, Writing Degree Zero (1953), the first Roland Barthes' book, consists of a history of modern literature from mid-nineteenth century to mid-twentieth. However, Barthes provides very few data about general history as well as about history of literature, what makes his first book hard to understand even today. This paper intends to discuss the possible meanings of these gaps, linking them to Barthes' aim (a story of modern literary forms). Then these possible meanings will be compared to the tone assumed by the essayist' writing on the history narrated by himself, in an attempt to identify and discuss their possible ambivalences.

\section{Resumé}

Premier livre de Roland Barthes, Le degré zéro de l'écriture (1953) voudrait être lu comme une histoire de la littérature moderne à partir de la moitié du dix-neuvième siècle, jusqu'à la moitié du vingtième. Toutefois, Barthes nous offre très peu de données sur l'histoire générale et sur l'histoire de la littérature, ce qui rend son premier livre difficile à comprendre, encore aujourd'hui. Cet article se propose de discuter le sens de ces lacunes, en les mettant à l'épreuve des buts déclarés par Barthes (de faire une histoire des formes littéraires modernes). Ensuite, ces lacunes sont aussi pensées par rapport au ton de cette écriture historique, à fin d'essayer d'identifier et de discuter ses ambivalences. 
O gran zero da escrita, de 1953, é a primeira e, ainda hoje, uma das mais controversas obras de Roland Barthes. Inicialmente, fora recebido como sendo uma espécie de debate de ocasião travado com O que é a literatura?, de Jean-Paul Sartre, em especial no que se refere às questóes que a história então recente (o período pósSegunda Guerra) impunha à literatura. Por mais que essa recepção inicial seja pertinente (ou quiçá justamente por sê-lo), fato é que, de tão enraizada, obliterou leituras do Grau zero per se, bem como maiores conjunçóes entre esse primeiro livro de Barthes e o restante de sua obra. Isto, a despeito de, no Grau zero, ser articulado, pela primeira vez, o conceito mais caro ao ensaísta ao longo de toda a sua trajetória intelectual, o de écriture. ${ }^{1}$

Por outro lado, é provável que esse relativo silêncio em torno do Grau zero para além do debate com Sartre também se dê em razão de sua singular relação com a história, e em dois âmbitos simultâneos: a maneira como se reporta à história geral, bem como, em especial, o desenvolvimento de seu principal objetivo (uma história das formas literárias modernas). A junção desses dois fatores implica uma série de lacunas típicas ao livro, de delicada e difícil compreensão ainda hoje. Por exemplo, a respeito de uma possível cronologia de autores e de obras característicos à modernidade a cuja história o Grau zero se dedica, escreve Philippe Roger: "esta cronologia fundadora é particularmente flutuante em Barthes [...]. Ele se exime, em geral, de toda categorização temporal que poderia lembrar a história literária tradicional: nunca a 'época' ou o 'período' (caracterizado por determinado autor ou 'escola') pontuam suas descriçóes do campo cultural.”* Traços como esse levam mesmo alguns críticos que têm Barthes em alta conta a atribuírem uma certa inconsistência à sua estreia editorial. Por exemplo, para Jonathan Culler:

\footnotetext{
${ }^{1}$ Há, certamente, exceçôes, tais como Vincent Jouve (La littérature selon Barthes. Paris: Minuit, 1986), Julia Kristeva (Sens et nonsens de la révolte: pouvoirs et limites de la psychanalyse. Paris: Fayard, 1996), Philippe Roger (Roland Barthes, roman. Paris: Grasset \& Fasquelle, 1986) e Susan Sontag ("Writing Itself: On Roland Barthes". Em: Where the Stress Falls. New York: Picador, 2012: 0133). De fato, esse isolamento atingiu tanto o Grau Zero quanto o segundo livro de Barthes, Michelet, de 1954; não por acaso, duas obras que lidam com a história de maneira muito pouco ortodoxa. De fato, só Mitologias, de 1957, seu terceiro livro, se revelou, de antemão, plenamente inteligível a seus contemporâneos; daí, inclusive, sua difusão à época, bem como seu papel fundamental, para crítica em geral, à reflexão ulterior do ensaísta.
}

* (ROGER, Philippe. Roland Barthes, roman. Paris: Grasset \& Fasquelle: 240, aspas do autor.) 
* (CULLER, Jonathan. Roland Barthes: A Very Short Introduction. 2. ed. New York: Oxford University Press, 2002: 21, grifos do autor, colchetes meus.)

* (BARTHES, Roland. "Le degré zéro de l'écriture". In: . OEuvres complètes: livres, textes, entretiens. Paris: Seuil, 2002: t. 5., p. 171, grifos do autor. Todas as demais citações de Barthes utilizadas neste artigo pertencem a essa mesma edição de suas obras completas, em cinco tomos.)
Este primeiro livro de Barthes, Le degré zéro, é um estranho trabalho de crítica. Poucas obras literárias são mencionadas e não há, praticamente, nenhum exemplo [...]. Mais tarde, em um artigo sobre história literária em Sur Racine, Barthes critica os historiadores da literatura por se valerem de um método histórico mas, ao mesmo tempo, negligenciarem a natureza histórica de seu objeto de estudo. Aqui, parece que vemos justamente o problema oposto: Barthes enfatiza o caráter histórico de seu objeto - escrita, ou a função literária - mas prescinde de um método histórico. A ideia de uma écriture classique mal é esboçada, e os leitores devem visualizar exemplos por conta própria. Barthes não analisa nem demonstra. Ele sequer responde a Sartre (o livro de Sartre [O que é a Literatura?] não é mencionado em parte alguma do texto)".*

Por que tais lapsos ou omissóes se fazem presentes no Grau zero? $\mathrm{O}$ que os incita e o que dão a ler? Em que medida podem ser considerados menos como uma eventual falha, como Culler o subentende, e mais como um traço próprio à verve ensaística pouco ortodoxa de Barthes? Este artigo pretende se ater, justamente, a tais questóes. Para tanto, trabalha-se com a hipótese de que tais omissóes possuem duas frentes interdependentes: de um lado, a particularidade mesma da história visada por Barthes no Grau zero; de outro, o tom assumido pelo ensaísta diante da história por ele mesmo narrada. É à exploração desses aspectos, bem como de suas potenciais ambivalências, que se dedica a reflexão a seguir.

\section{Fragmentos de um discurso histórico}

A história da modernidade articulada por Barthes no Grau zero é norteada por um horizonte ético subjacente ao conceito de escrita. Mais especificamente, a Barthes, interessa a compreensão de "uma escrita cuja função não mais consiste em meramente comunicar ou exprimir, mas em impor um para além da linguagem que é, ao mesmo tempo, a História e o partido que nela se toma”. * Ainda que aí a ligação entre escrita e história seja firmada de modo categórico, não o é de modo unívoco. Se a escrita, pois, para Barthes, é um "para além da comunicação e da expressão", por esse "para além" se subentende, dentre outras coisas, para além da comunicação e da expressão de determinados conteúdos usualmente considerados históricos, tais como o cronológico-factual. Por exemplo, ao falar da escrita no romance moderno (pós-1848) e de sua relação com a história, o ensaísta se atém ao uso do passé simple e do narrador em terceira pessoa, nada havendo sobre a representação da vida 
social nem do sujeito modernos, como encontramos, em maior ou menor grau, em diversas das mais difundidas reflexôes sobre a narrativa moderna, tais como as de Theodor W. Adorno, ${ }^{*}$ Erich Auerbach, ${ }^{*}$ Walter Benjamin, ${ }^{*}$ Lucien Goldmann. ${ }^{*}$ Nesse sentido, é a falta de conteúdo factual-cronológico aquilo que, como já visto em relação ao Grau zero, Philippe Roger identifica, bem como aquilo que Jonathan Culler sanciona. Essa falta é indicativa da singularidade da história almejada no Grau zero: não se trata de uma história daquilo que, usualmente, consiste a representaçáo literária (temas, enredos, personagens, imagens, etc.); trata-se, antes, de uma história da escrita moderna, isto é, dos traços a partir dos quais, para Barthes, a literatura se firma como tal na modernidade.

Se o ensaísta prescinde daquilo que se representa na literatura moderna ao dirigir suas atençóes à escrita, há, no Grau zero, algumas tentativas afins a um vínculo entre a história geral (naquilo que, nela, é cronológico-factual) e a escrita. Mas se trata de uma equação problemática, porque sempre (e, muitas vezes, não satisfatoriamente) resolvida em favor da escrita. Philippe Roger descreve essa hesitação de Barthes nos seguintes termos:

[...] em torno do "moderno", um torniquete se instaura em seus textos, refletindo uma ambivalência entre um gosto "sociológico" na designação das produçóes culturais e aquilo que podemos chamar de uma pulsão "formalista" - que é, também ela, por um paradoxo que lhe é próprio [a Barthes], uma reivindicação de "valor". [...] é em favor da segunda que pende toda a coletânea [isto é, os textos recolhidos no Grau zero].*

Ou seja, Barthes arrola determinados eventos históricos tentando, por meio deles, justificar os impasses da escrita na modernidade. Mas a suscetibilidade própria a seu conceito de escrita, afora ser ela um valor para o ensaísta, impelem-no a seguir tratando de aspectos tais como o passé simple no romance, como que abandonando a história geral. De certo modo, essa faceta do Grau zero parece evidenciar um problema ao qual Barthes só se reportaria mais tarde, em "História ou literatura" (justamente o ensaio incluído em Sobre Racine ao qual se refere Culler):

[...] não só não se pode tratar a literatura como qualquer outro produto histórico (o que ninguém pensaria ser razoável), como também essa especialidade da obra contradiz, em certa medida, a história, em suma, a obra é essencialmente paradoxal, pois é, ao mesmo tempo, signo de uma história e resistência a essa história.*
* (ADORNO, Theodor W. "Posição do narrador no romance contemporâneo". In Notas de literatura l. Tradução de Jorge de Almeida. São Paulo: Duas Cidades; Ed. 34, 2003: p. 55-63.

* (AUERBACH, Erich. "A meia marrom". In:

Mimesis: a representação da realidade na literatura ocidental. [Vários Tradutores] 5. ed. São Paulo: Perspectiva, 2007: 471-498)

* (BENJAMIN, Walter. "O narrador: considerações sobre a obra de Nikolai Leskov". In: _____. Magia e técnica, arte e política: ensaios sobre literatura e história da cultura. Trad. Sérgio Paulo Rouanet. 7. ed. 10 reimpr. São Paulo: Brasiliense, 1996: 197-221)

* (GOLDMANN, Lucien. Pour une sociologie du roman. Paris: Gallimard, 1966) ou Georg Lukács (LUKÁCS, Georg. A teoria do romance: um ensaio histórico-fi losófico sobre as formas da grande épica. Trad; José Mar cos Mariani de Macedo. São Paulo: Duas Cidades; Ed. 34, 2000.)

* (ROGER, Philippe. Ro land Barthes, roman, op. cit.: 241-242, aspas do autor, colchetes meus.)

* (BARTHES, Roland. "Sur Racine". In:_. OEuvres complètes, op. cit.: t. 2, 178.) 
* (BARTHES, Roland. "Mythologies". In: CEuvres complètes, op. cit.: t. 1,846.)

* (DE MAN, Paul. "Roland Barthes and the Limits of Structuralism". Yale French Studies, New Haven, n. 77, 1990: 183.)

* (BARTHES, Roland. "Le degré zéro de l'écriture". In: _._._Euvres complètes, op. cit: t. 1, 171, grifos do autor.)
Deslocando essas observaçóes ao Grau zero, em que medida traços como o passé simple e a narração em terceira pessoa do romance têm a propriedade de assinalar a história e, em um mesmo lance, a tomada de partido do escritor diante dela, impondo-se como signo da história e, simultaneamente, signo de uma resistência a ela? Ainda que o caráter lacunar do Grau zero náo facilite um pleno entendimento disso, a atenção a aspectos deste tipo é táo representativa da maneira como Barthes se fez como crítico que se pode encontrar casos afins ao longo de toda sua obra. Aliás, por isso que o Grau zero nada tem de extemporâneo ou apócrifo no contexto da obra de Barthes; é, antes, um primeiro passo rumo a uma reflexão cujas tantas reviravoltas (suas tantas fases) a esclarecem na medida mesma que a modificam. E Barthes demonstra uma aguda consciência disso. Um caso afim, relevante à reflexão aqui traçada, se encontra em Mitologias, mais precisamente, quando, nele, o ensaísta concebe o Grau zero como sendo uma "mitologia da linguagem literária".* Mitologias, como se sabe, é dedicado à leitura de diversos textos veiculados pela cultura de massa francesa de meados dos anos cinquenta, tais como notícias de jornal, propagandas, eventos quotidianos, etc. Nessas leituras, seu principal interesse é compreender o processo segundo o qual valores historicamente construídos se passam por factuais ou atemporais. Conforme Paul De Man, isso só é possível em razão da atenção dada por Barthes àquilo que, em geral, é tomado por supérfluo:

[...] os gestos mais supérfluos são os mais propensos a se tornarem imprescindíveis. Sua artificialidade aguda lhes doura com uma máxima feição de naturalidade. Ficçōes e mitos são viciantes porque substituem as necessidades naturais ao se tornarem mais naturais do que a natureza por eles deslocada. ${ }^{*}$

Traçando um paralelo entre essas observaçóes de Paul De Man e o Grau zero, pode-se dizer que Barthes se atém àquilo que, na escrita literária, poderia passar por supérfluo (por exemplo, o passé simple do romance), ou seja, justamente, aos traços por meio dos quais "a literatura se impóe como tal", que a diferenciam das demais escritas, que a inscreve como:

[...] a solidão de uma linguagem ritual. Essa ordem sacra dos Signos escritos coloca a Literatura como uma instituição e tende evidentemente a abstraí-la da História, pois nenhum fechamento se funda sem uma ideia de perenidade; ora, é aí onde a História é recusada que ela age mais claramente.* 
Se, em Mitologias, Barthes empreende essa reflexão a partir de textos veiculados pela cultura de massa, bem se sabe que, no Grau zero, o ensaísta prescinde desta leitura de textos específicos, o que torna sua reflexão algo abstrata, quase aforística. Isso, porém, é parcialmente compreensível à medida que, ao contrário dos signos da cultura de massa, a literatura (moderna ou não) tem seu valor mais do que assegurado socioinstitucionalmente. Ou seja, Barthes se viu como que dispensado dessa tarefa no que compete à literatura, mas não no que compete aos signos da cultura de massa, mesmo porque esses, antes dele, eram pouco ou nada considerados dignos de nota. Não que ele não pudesse ou não precisasse fazê-lo em se tratando da literatura. De fato, se o fizesse, isso daria outra amplitude ao Grau zero. A ausência disso, ainda que dificulte a leitura do livro, não a impede certamente. ${ }^{2}$

Em resumo, para Barthes, não é a tematização da vida social aquilo que firma a tomada de partido do escritor diante da história. Isso é feito, antes, por meio dos traços estritamente formais (para muitos, supérfluos) por meio dos quais a literatura se impóe como tal. E, a Barthes, interessa, nesses traços, a assunção de um tom por parte do escritor, pois é essa assunção aquilo que o inscreve na história: "Não importa em qual forma literária, há escolha geral de um tom, de um éthos, se quiser, e é aí, precisamente, que o escritor se individualiza claramente porque é aí que ele se engaja."* Este tom ou ethos, ${ }^{3}$ conjunção entre a impessoalidade da língua (patrimônio comum, totalmente independente do escritor) e a brutalidade do estilo (os traços psíquico-corpóreos do sujeito, anteriores à socialização), corresponde a uma certa disposição ético-afetiva do escritor diante da escrita e, com efeito, diante da história, indiciando sua tomada de partido aí.

Verdade que os efeitos e sentidos desta escolha escapam ao escritor conforme sua escrita passa a circular no bojo da vida social. Mas, para Barthes, a instabilidade subjacente a esta inscrição não

\footnotetext{
${ }^{2}$ Pode-se perguntar, inclusive, em que medida Barthes já não o fizera, mesmo que parcialmente, em alguns artigos esparsos publicados antes do Grau zero, tais como "Reflexóes sobre o estilo de O estrangeiro" (Ibidem: 75-79.) e "Jean Cayrol e seus romances". (Ibidem: 141-162.)

${ }^{3}$ Dentre os graus afetivos hábeis à realização da persuasio na retórica clássica, "O grau mais suave de afectos, que aparece como um estado de alma permanente e que também pode ser valorizado como carácter, chama-se ethos." (LAUSBERG, Heinrich. Elementos de retórica literária. Trad. R. M. Rosado Fernandes. 5. ed. Lisboa: Fundação Calouste Gulbenkian, 2004: 105, \$ 69, grifos do autor).
} 
compromete, em nada, sua importância. Pois a escrita "não é liberdade senão no gesto da escolha, mas não mais em sua duração. [...] Como Liberdade, a escrita é, portanto, um momento apenas. Mas este momento é um dos mais explícitos da História, pois a História é, sempre e antes de tudo, uma escolha e os limites dessa escolha."* $\mathrm{E}$ um outro fator que concorre a essa efetividade apenas circunstancial da escrita tem a ver com as distintas temporalidades aí atuantes. Dizendo de outro modo, por mais que seja por meio da escrita que o escritor ingresse na história, a história das formas é, para Barthes, regulada por uma temporalidade distinta da história geral. De certo modo, isso explica a dificuldade do ensaísta em traçar paralelos entre a história geral e a história das formas, como aqui já assinalado por Philippe Roger. Ironicamente, muitos desses paralelos só são bem-sucedidos quando se prestam à afirmação da diferença temporal entre ambas. É este, justamente, o caso da presença da escrita clássica (isto é, uma escrita socialmente tanto homogênea quanto hegemônica) em um período supostamente pós-clássico (isto é, após a Revolução Francesa), como o descreve Barthes:

[...] a Revolução Francesa não modificou as normas dessa escrita [clássica], porque o pessoal pensante permanecia, afinal, o mesmo e apenas passava do poder intelectual ao poder político [...]. Os revolucionários não tinham razão alguma para quererem modificar a escrita clássica, eles não cogitavam, absolutamente, pôr em xeque a natureza do homem, menos ainda sua linguagem, e um "instrumento" herdado de Voltaire, de Rousseau ou de Vauvenargues não lhes podia parecer comprometido.*

Ou seja, como a revolução não implicou qualquer alteração na escrita, supóe-se, a partir disso, que, no Grau zero, literatura e história, por mais que se afetem mutuamente (em especial, a literatura pela história), possuem diferentes modulações temporais. Alteraçôes de ordem histórica podem não implicar alteraçôes na escrita. E, mesmo quando o implicam, não se trata de algo compulsório, muito menos diretamente proporcional - a propósito: eis, aí, uma escrita que é signo da história e, ao mesmo tempo, signo de uma resistência a essa mesma história, como o dissera Barthes em "História ou literatura”. Por esse viés, no Grau zero, um dos traços mais característicos ao diálogo entre história e literatura diz respeito a um certo atraso das formas, o que, embora não inviabilize qualquer conjunção entre ambas, torna esse processo pouco unívoco. Com efeito, no Grau zero, por mais que a escrita e a história dialoguem 
entre si (ou, dada a dimensão ética em pauta, devam dialogar), tratam-se de coisas diferentes ou, pelo menos, que possuem diferentes temporalidades (o atraso das formas que vimos o comprova). Mais uma vez, portanto, a ausência de um determinado método histórico ortodoxo no Grau zero não é, de modo algum, uma falha per se. É, antes, indicativo de que a história a que Barthes visa é, simplesmente, diferente da história geral.

\section{Os tons do presente}

Se, conforme uma célebre passagem do prefácio a seus primeiros Ensaios críticos, Barthes compreende que também "o crítico é um escritor" - qual é o tom que ele, como escritor-crítico que é, assume no Grau zero? Essa questáo implica uma especulação sobre o cruzamento promovido pelo Grau zero entre aquilo que nele se diz e aquilo que ele, como texto que é, faz. Isso, além de ser, por si só, capaz de alterar, e substancialmente, o que se diz no Grau zero, também engloba o horizonte crítico por Barthes projetado diante da história que ele próprio constrói e com a qual lida invariavelmente.

Por esse viés, não é difícil reconhecer que, em princípio, o Grau zero se dirige a seu presente, à busca por resolução de problemas que a história (em especial, a partir de meados do século XIX) impóe à escrita de seu presente. Todas as recensóes a respeito de um passado recente, condizentes com a instauração da modernidade, buscam mapear de que maneira os escritores lidaram com tais imposições nos últimos cem anos, isto é, de que forma situaram sua escrita diante da história, e de que maneira ainda é possível fazê-lo em meados dos anos cinquenta do século XX. Mas o grande problema é que, por mais que algumas dessas escritas tenham sido extremamente válidas em seu trato com a história (em especial, a escrita de Flaubert, quase um paradigma para Barthes desde o Grau zero até seus últimos escritos), sua efetividade não é mais possível em meados do século XX. Sobretudo, em razão das diferentes temporalidades que regem, de um lado, a história das formas e, de outro,

\footnotetext{
${ }^{4}$ Eis a passagem completa: “[...] mesmo se, por função, o crítico fala da linguagem dos outros a ponto de, aparentemente (e, por vezes, abusivamente), querer concluí-la, o crítico, da mesma maneira que o escritor, não tem, nunca, a última palavra. Ademais, este mutismo final que forma sua condição comum, é ele que desvenda a identidade verdadeira do crítico: o crítico é um escritor." (BARTHES, Roland. "Essais critiques". In: Euvres complètes: t. 2, 273, grifos do autor.)
} 
* (BARTHES, Roland. "Le degré zéro de l'écriture". In: . CEuvres complètes, op. cit.: t. 1, 171-172, grifos do autor.)

* (Ibidem: 54 .) a história geral, o que, como vimos, se vincula ao fato de a inscrição do escritor na história por meio da escrita ser um gesto efetivo na medida mesma em que apenas circunstancialmente válido. Daí sua especulação a respeito de uma escrita neutra, isto é, aquela que, em meados do século XX, busca se inscrever na história por meio de um tom despido de ênfase e de qualquer anseio por transcendência, tais como, no Grau zero, as de Albert Camus, Jean Cayrol e Maurice Blanchot (mencionados mas não textualmente citados).

A escrita do Grau zero, entretanto, se distancia, em muito, do tom neutro, para Barthes, mais apropriado ao presente. Não só porque esse presente é um impasse per se, mas também por ele ser como que assombrado pelo passado recente. Por exemplo, logo na introdução ao Grau zero, lê-se que:

Ver-se-á, por exemplo que a unidade ideológica da burguesia produziu uma escrita única, e que, nos tempos burgueses (ou seja, clássicos e românticos), a forma não podia ser dilacerada à medida que a consciência não o era; e que, ao contrário, desde o instante a partir do qual escritor deixou de ser uma testemunha do universal para se tornar uma consciência infeliz (por volta de 1850), o seu primeiro gesto foi escolher um engajamento com a sua forma, seja assumindo, seja recusando a escrita de seu passado. A escrita clássica, assim, explodiu, e toda a Literatura, desde Flaubert a nossos dias, tornou-se uma problemática da linguagem.*

Ora, "dilaceramento da consciência" proporcional ao da própria "forma"; "assunção" ou "recusa" da escrita passada; "explosão da forma" seguida da conversão da literatura em um "problema" - bem se vê o quanto, para Barthes, a modernidade é o tempo de uma "consciência infeliz" . 5 e fato, mais do que "problemática", a modernidade é "trágica": "o escritor se torna a presa de uma ambiguidade, pois sua consciência não recobre mais exatamente sua condição. Assim, nasce um trágico da Literatura. [...] o que a modernidade dá a ler, na pluralidade de suas escritas, é o impasse de sua própria História."*

\footnotetext{
${ }^{5}$ Em 1956 (isto é, três anos após a publicação do Grau zero), Barthes escreve um prefácio a uma ediçấo dos romances e contos de Voltaire intitulado "O último dos escritores felizes". (Ibidem: t. 2, 352-358.) Posteriormente reunido junto a seus primeiros Ensaios críticos, este ensaio mapeia as condiçóes tanto sociais quanto político-institucionais que propiciaram o surgimento da consciência infeliz tão recorrente à modernidade no Grau zero por meio de seu contraste com as unívocas possibilidades de engajamento à época de Voltaire.
} 
Este léxico do qual se vale Barthes no Grau zero configura um impasse histórico que, para o escritor, impóe a necessidade de uma escolha fatalmente trágica. Por mais que suas razóes sejam compreensíveis - afinal, afora as questôes próprias à modernidade, Barthes escreve ainda em meio aos ecos da Segunda Guerra - há outros fatores que precisam ser levados em conta nessa construção do presente. Por esse viés, em "Figuras do presente", ensaio no qual trata da maneira como a crítica brasileira moderna e contemporânea constrói uma dada imagem do presente para, então, justificar a si mesma, o poeta e crítico Marcos Siscar considera que:

Não há neutralidade no cálculo do presente. Há, sim, uma montagem na produçấo e na veiculaçáo da informaçáa, na produçáo e na veiculação do saber cujo reconhecimento, por parte do teórico, nem sempre tem consequências na sua prática. O presente se constitui, antes de mais nada, como um efeito de atualidade, como algo que tornamos atual para a consciência através de um ato de atenção; existe uma intencionalidade que é preciso considerar [...]. Não há atualidade sem intencionalidade, sem exercício de atenção por parte de um olhar. Em outras palavras, não há presente sem interpretação. [...] heterogênea à observação totalizadora, a montagem da atualidade é um processo que recorta, seleciona, privilegia, exclui o excedente; como tal, ela é também supressiva, excludente, expulsando pela sua tendência de anular a diferença.*

A passagem tem um duplo interesse a esta reflexão. Primeiramente, porque a própria noção de modernidade cunhada por Barthes condiz, perfeitamente, com uma dada montagem do presente cuja intenção última é legitimar sua tragicidade. Em seguida, porque, nessa operação, Barthes se vale de toda uma série de cortes, de exclusóes, de lapsos, abordados desde o segundo parágrafo da reflexão aqui traçada. De modo que é importante repensarmos esses cortes, agora, em função do presente rumo ao qual converge a história narrada no Grau zero.

Logo de início, vale dizer que a retórica da urgência, da qual se vale Barthes, em razão do tom dramático que lhe é subjacente, é aquilo que motiva os tantos cortes, os tantos lapsos operados tanto sobre o presente quanto sobre o passado recente. Dentre esses, dois são os mais evidentes: o trato de textos específicos e aquilo que chamamos de cronológico-factual. Já vimos que a exclusão do cronológico-factual se encontra motivada e, em certa medida, justificada pela proposta mesma do livro: a Barthes, interessa traçar não uma história geral literatura moderna, mas, tão-somente, uma história
* (SISCAR, Marcos. "Figuras do presente". In:__. Poesia e crise: ensaios sobre a "crise da poesia" como topos da modernidade. Campinas: Unicamp, 2010: 188189, grifos do autor.) 
da escrita moderna. Mas o descarte de textos específicos, por mais que seja compreensível diante da urgência inerente ao relato, guarda alguns traços retóricos mais sutis, potencialmente esclarecedores do tom assumido por Barthes. Aí, mais especificamente, interessa a maneira por meio da qual Barthes concebe e sanciona as escritas modernas por ele abordadas alusivamente no Grau zero; alusivamente porque não concretamente exemplificadas. Nesse caso, pois, não se trata de um procedimento estritamente motivado pela particularidade da história visada na obra, como o é a supressão do cronológico-factual. Trata-se, antes, de uma estratégia retórica bem mais ambivalente.

Em meio à comparação do Grau zero a Mitologias, vimos que Barthes, em seu primeiro livro, prescinde da menção a textos específicos em razão de a literatura ter seu valor mais do que assegurado socioinstitucionalmente, ao contrário dos signos da cultura de massa abordados em Mitologias. É possível, agora, acrescentar mais um fator a isso. Ao se referir ao processo de concreção da escrita, o qual dificulta sua relação direta com a história à medida que ela própria, a escrita se torna um problema intransponível para o escritor, escreve Barthes (em uma das poucas recensōes cronológicas encontráveis no Grau zero):

Todo o século XIX viu progredir esse fenômeno dramático da concreção. Em Chateaubriand, ainda não passa de um fraco depósito, o peso ligeiro de uma euforia da linguagem, um tipo de narcisismo em que a escrita se separa muito pouco de sua funçáo instrumental e náo faz mais do que contemplar a si mesma. Flaubert - para náo indicar aqui senão os momentos típicos deste processo - constituiu definitivamente a Literatura como objeto, pelo advento de um valortrabalho: a forma tornou-se o termo de uma "fabricação", como uma cerâmica ou uma joia (deve-se ler que a fabricaçâo foi "significada", isto é, pela primeira vez, entregue como espetáculo e imposta). Mallarmé, enfim, coroou essa construçáo da Literatura-Objeto pelo ato último de todas as objetivaçôes, o homicídio: sabe-se que todo o esforço de Mallarmé visava a uma destruição da linguagem, da qual a Literatura não seria mais que o cadáver.

Partindo de um nada em que o pensamento parecia se elevar alegremente sobre o cenário das palavras, a escrita, assim, atravessou todos os estados de uma solidificação progressiva; de início, objeto de um olhar, depois de um fazer e, enfim, de uma morte, ela chega, hoje, a um último avatar, a ausência: nessas escritas neutras, aqui chamadas de "o grau zero da escrita", pode-se facilmente discernir o movimento mesmo de uma negação, e a impotência de completá-lo em uma duração, como se a Literatura, tendendo, faz um século, 
a transmudar a sua superfície em uma forma sem hereditariedade, não encontrasse mais pureza senão na ausência de todo signo, propondo, enfim, o cumprimento desse sonho órfico: um escritor sem literatura.*

As etapas aí descritas por Barthes são aquelas, de fato, decisivas à sua concepção de escrita moderna. ${ }^{6}$ Por mais eficazes que tenham sido à sua época, tais escritas não são passíveis de repetição como tais, já que, como o vimos, uma tal função é inversamente proporcional à sua duração - mais um fator, portanto, do trágico da modernidade. Mas, por outro lado, esta eficácia, porque diretamente vinculada a uma escolha diante da história, pode, sim, ser repetida, desde que por outras vias, isto é, por meio de outras escritas. Daí, precisamente, o valor das escritas neutras: elas são uma busca por esta inscrição no presente, mesmo porque Camus, Cayrol e Blanchot ainda enfrentam o mesmo problema pelos quais passaram Flaubert e Mallarmé. A diferença cronológica entre as escritas neutras e esses escritores do século XIX é indicativa de uma afinidade muito mais profunda. A história da escrita moderna, para Barthes, prescinde de um télos, sendo também isso parte integrante sua tragicidade (uma tragicidade, por assim dizer, materialista).

Mas, no Grau zero, grande parte das escritas modernas abordada por Barthes consiste na repetição não da eficácia de um Flaubert ou de um Mallarmé mas, antes, na mera repetição de uma versão já narcotizada destas escritas; repetição, esta, não mais válida (lembrando: para Barthes, a liberdade do escritor se encontra no gesto mesmo de sua escolha, e não na duração deste gesto). $\mathrm{E}$, ainda mais, à medida que uma tal repetição, em vez de inserir o escritor na história, visa a uma apropriação sub-reptícia da inserção efetuada por outrem. Ou seja, trata-se de um gesto afim a uma irresponsabilidade da forma: a escrita aí adotada não é escolhida pelo próprio escritor, que simplesmente a repete; se ele dissimula sua omissão ao delegar a responsabilidade por esta escolha a outrem, não abre mão, entretanto, da suposta eficácia dessa escolha (que, ademais, com bem o assinala Barthes, ele não fez). Daí que tal apropriação é, para o ensaísta, além de vã, eticamente reprovável. Para ficarmos em um exemplo, no que se refere às escritas políticas

\footnotetext{
${ }^{6}$ Há algumas variações desta história em escritos posteriores de Barthes; variaçôes, estas, que acrescentam um ou outro nome, descrevem um ou outro fator novo mas que, ao cabo, permanecem bastante afins a essa passagem do Grau zero. Um bom exemplo disso é o ensaio "Literatura e metalinguagem". (Ibidem: t. II, 364-365.)
}

* (BARTHES, Roland. "Le degré zéro de l'écriture". In: . CEuvres complètes, op. cit.: t. 1, 172-173, aspas e grifos do autor. 
comuns aos periódicos Esprit e Les Temps Modernes (este, como se sabe, dirigido por Sartre):

Aderir a uma palavra fechada pela pressão de todos aqueles que não a falam é manifestar o movimento próprio de uma escolha, senão defender essa escolha; a escrita se torna aqui algo como uma assinatura que se apóe abaixo de uma proclamação coletiva (que não foi, ademais, redigida pela própria pessoa). Assim, adotar uma escrita - poder-se-ia dizer ainda melhor - assumir uma escrita - é fazer a economia de todas as premissas da escolha, é manifestar como aceitas as razóes dessa escolha. [...] Ao passo que uma linguagem idealmente livre nunca poderia apontar à minha pessoa ignorando minha história e minha liberdade, a escrita à qual me entrego é já toda instituição; ela desvenda meu passado e minha escolha, ela me dá uma história, ela escancara minha situação, ela me engaja sem que eu precise dizê-lo. A Forma se torna, assim, mais do que nunca, um objeto autônomo, destinado a significar uma propriedade coletiva e resguardada, e esse objeto tem valor de investimento, ele funciona como um sinal econômico graças ao qual o scripteur impóe, incessantemente, sua conversão sem jamais descrever sua história.*

As demais escritas abordadas no Grau zero, com exceção das neutras, padecem desse mesmo problema, isto é, a obliteração do caráter trágico e fundador da modernidade. Obliteram-no por meio de procedimentos que, para Barthes, não são sequer paliativos; são, pelo contrário, irresponsáveis, como que o avesso da moralidade da forma pela qual tanto reclama no Grau zero. Por isso, em vez de tratar de textos específicos, Barthes prefere lidar com uma versão sintético-abstrata das escritas às quais se atém. Daí, a propósito, as ausências tanto da menção a quanto da abordagem de textos específicos.

Trata-se de uma estratégia retórica relativamente justificável em razão do caráter urgente do relato, bem como do rebaixamento da dimensão ético-formal promovido por estas escritas modernas aos olhos do ensaísta; isto, afora a propriedade com que Barthes formula essas versóes sintético-abstratas. Mas, ao mesmo tempo, tais versóes, por mais pertinentes que sejam, podem induzir à perda de uma justa medida na sanção das escritas analisadas. Em especial, porque os traços selecionados por Barthes em sua síntese são, evidentemente, aqueles que mais e melhor se coadunam à sua própria reflexão. Fatalmente, as eventuais dissonâncias aí encontráveis são obliteradas. Sendo este o caso, oblitera-se, justamente, aquilo que poderia alterar o panorama traçado por Barthes, suscitando, 
por exemplo, alguns ajustes tanto na instauração da modernidade quanto nas propriedades desta e de seu presente.

No Grau zero, o momento mais flagrante em que essa ambivalência se manifesta é no trato da poesia (da moderna, em especial). Vimos que as ambivalências próprias ao tom assumido pela política e pelo romance não arriscam, contudo, seu status de escrita, isto é, o de uma dada conjunção entre língua (patrimônio comum, totalmente independente do escritor) e estilo (os traços psíquicocorpóreos do sujeito, anteriores à socialização) capaz de projetar a história e, ao mesmo tempo, o partido que nela toma o escritor. Já a poesia moderna, para Barthes, sequer se constitui como tal, como escrita: "Nesse momento [início da década de 1950], dificilmente se pode falar de uma escrita poética, já que se trata de uma linguagem cuja violência de autonomia destrói qualquer alcance ético. $\mathrm{O}$ gesto oral, aqui, visa modificar a Natureza; é uma demiurgia; é não uma atitude de consciência, mas um ato de coerção". ${ }^{77}$ Dois fatores possibilitam a uma formulação como essa. Em princípio, a circunscrição daquilo que Barthes compreende por poesia moderna a uma vertente pura e/ou hermética, a despeito das tantas outras vertentes da poesia na modernidade.* Isto, para não mencionar que mesmo sua suposta violência de autonomia pode, por si só, ser revogável.* Em seguida, o tom assumido pela poesia moderna, mesmo que distinto das escritas neutras visadas no Grau zero, também se constitui, inegavelmente, em um determinado engajamento na forma e, a partir daí, na história. Aliás, ainda que a retórica da urgência comum a essa obra seja dificilmente conciliável com agressividade própria, para Barthes, à poesia moderna, fato é que ambas se aproximam

\footnotetext{
${ }^{7}$ De fato, surpreende que, mesmo sessenta anos após a publicação do Grau zero, a delicada relação de Barthes com a poesia tenha sido assinalada por pouquíssimos críticos. (Cf. COMPAGNON, Antoine. "Le roman de Roland Barthes". Critique, Paris, n. 678, nov. 2003: 799; DEGUY, Michel. "R.B. par M.D”. Rue Descartes, Paris: P.U.F., n. 34, v. 4, 2001: 11; JOUVE, Vincent. La littérature selon Barthes, op. cit.: 09; MOTTA, Leda Tenório da. Roland Barthes: uma biografia intelectual. São Paulo: Iluminuras; FAPESP, 2011: 98.) Difícil dizer por quais razóes, ainda que, provavelmente, uma delas diga respeito ao desconforto de uma tal constatação. Afinal, Barthes é um dos críticos mais sensíveis à linguagem da segunda metade do século XX, cuja reflexão é mais do que condizente, e em diversos níveis, com a poesia moderna (como bem o notam os já citados Michel Deguy e Leda Tenório da Motta). De modo que, para aqueles que têm certo apreço tanto pela obra do ensaísta quanto pela poesia, a rejeição de Barthes a ela pode soar um disparate. Mas essa rejeição, de fato, existe, e categoricamente, no Grau zero.
}

* (Ibidem: t. 1, p. 201, colchetes meus.)

* (Cf., p. ex., BERARDINELLI, Alfonso. Da poesia à prosa. Org. Maria Betânia Amoroso. Trad. Maurício Santana Dias. São Paulo: Cosac Naify, 2007; HAMBURGER, Michael. A verdade da poesia: tensões na poesia modernista desde Baudelaire. Trad. Alípio Correia de Franca Neto. São Paulo: Cosac Naify, 2007.)

*(Cf., p. ex., DE MAN, Paul. "Lyric and Modernity". In: Blindness and In-

sight: Essays in the Rhetoric of Contemporary Criticism. 2. ed. rev. Minneapolis: University of Minnesota Press, 1983: 166-186.) 
bastante no que compete à tragicidade da modernidade. Verdade que, em Barthes, muito desta tragicidade se dá em razão de seu apego a valores clássicos, ${ }^{8}$ tal como a defesa de uma sutil transparência da escrita mesmo na modernidade (mais um traço, aliás, do atraso das formas próprio ao Grau zero). Mas, mesmo que o caráter trágico da modernidade só se dê a ler na poesia moderna, se ela for tomada como que a contrapelo (isto é, pelo que ela exclui no gesto mesmo de sua inscrição), trata-se de algo plenamente assimilável à reflexão travada no Grau zero. Daí que a exclusão sumária da poesia moderna da história das formas (sendo Mallarmé a única exceção, já que esporadicamente mencionado, ainda que nunca efetivamente discutido) pode ser lida menos como índice de uma suposta inviabilidade do diálogo entre poesia e história e mais como uma limitação mesma da retórica da urgência do Grau zero.

\section{Considerações finais}

De um lado, as circunstâncias próprias à época de sua publicação (o período pós-guerra, a sombra onipresente de Sartre subjacente à enorme recorrência ao termo engajamento, etc.), juntamente com aquilo que chamamos de retórica da urgência, distanciam o Grau zero daquilo que Barthes veio a escrever depois (em especial, a partir de Mitologias e de sua adesão inicial ao Estruturalismo). Mas, ao mesmo tempo, é inegável que muito do firmado no Grau zero permanece como traço definidor da reflexão ulterior do ensaísta. Por exemplo, questôes afins às escritas neutras são retomadas em seu penúltimo curso ministrado junto ao Collège de France, intitulado,

* (BARTHES, Roland. Le neutre. Paris: Seuil; Imec, 2002.)

* (COMMENT, Bernard. Roland Barthes: vers le neutre. Paris: Christian Bourgeois, 1991.)

* (Roland Barthes: uma biografia intelectual. São Paulo: Iluminuras; FAPESP, 2011.)

* (BARTHES, Roland. CEuvres complètes, op. cit.: t. IV, 217-264.) justamente, $O$ neutro, ${ }^{*}$ cujo potencial vínculo com as formulaçóes do Grau zero é bastante explorado por Bernard Comment* e, em especial, por Leda Tenório da Motta.* Isto, para não dizer do tom aforístico, tão característico de alguns de seus trabalhos mais difundidos, como O prazer do texto. *

${ }^{8}$ Como bem o descreve Philippe Roger: "O paradoxo, entretanto, é que a posição da Modernidade, em Barthes, é frequentemente acompanhada por um cortejo de associaçôes eminentemente clássicas. E essas 'ideias acessórias' - o velho estilo tomado por 'conotaçóes' - dão-se a ler essencialmente como um rasgo. De tal modo que perdura, do Grau zero... a quaisquer de suas últimas intervençóes sobre o 'romanesco' [Roger se refere ao último curso de Barthes ministrado no Collège de France], a surda convicçâo de um trágico da Modernidade.” (ROGER, Philippe. Roland Barthes, roman, op. cit.: p. 241, aspas e grifos do autor, colchetes meus. A esse respeito, cf. COMPAGNON, Antoine. Les antimodernes: de Joseph de Maistre a Roland Barthes. Paris: Gallimard, 2005: 404-440.) 
Há, ainda, dois outros aspectos. O primeiro diz respeito à especial atenção dada por Barthes à dimensão ético-afetiva mesmo em relação a fatores, em tese, dela táo distantes, como a história geral. Esta conjunção entre forma e afeto (ou, ainda, forma e corpo) em constante contraposiçâo com história, com a política, em suma, com a vida social como um todo é extremamente constante em sua reflexão ao longo das décadas seguintes. Já o atraso das formas, característico ao Grau zero, assinala, de antemão, a singularidade crítica de Barthes, distanciando-o de paradigmas correntes à esquerda ortodoxa de sua época, como as associações mecânicas entre a literatura e história, justificando, plenamente, sua adesão inicial ao Estruturalismo. Isto, afora a incompatibilidade entre esse atraso e concepções te(le)ológicas tanto de história geral quanto de história das formas; incompatibilidade, esta, que, para além do contexto da obra de Barthes, pode ser, hoje, extremamente válida a reflexóes sobre a literatura e a cultura contemporâneas.

Márcio Renato Pinheiro da Silva é doutor em Letras (Teoria da Literatura) pela Universidade Estadual Paulista (Unesp 2008). Desde 2009, é professor Adjunto de Teoria Literária da Universidade Federal do Rio Grande do Norte (UFRN), campus de Currais Novos (RN). É autor de $A$ Aporia do Sentido (Annablume/Fapesp) e de alguns artigos e ensaios sobre Teoria Literária, em especial, sobre Roland Barthes, e sobre Literatura Brasileira Contemporânea, incluindo Dalton Trevisan, João Gilberto Noll, Bernardo Carvalho, Orides Fontela e Armando Freitas Filho. Atualmente faz pós-doutorado com bolsa FAPESP. E-mail:<mrenatops@uol.com.br>. 